\title{
INFLUENCE OF LOCAL RECURRENCE ON THE PROGNOSIS OF SOFT-TISSUE SARCOMAS
}

\author{
TAKAFUMI UEDA, HIDEKI YOSHIKAWA, SHIGEKI MORI, NOBUHITO ARAKI, AKIRA MYOUI, \\ SHIGEYUKI KURATSU, ATSUMASA UCHIDA \\ From Osaka Medical Centre for Cancer and Cardiovascular Diseases and Osaka University Medical \\ School, Osaka, Japan
}

We have investigated the significance of local recurrence on survival in 173 patients with localised soft-tissue sarcomas of the limbs and of the trunk.

The overall survival rates at five and ten years were $\mathbf{7 5 . 2 \%}$ and $\mathbf{6 8 . 0 \%}$, respectively. After definitive surgery at our hospitals, there was local recurrence in 25 patients $(14.5 \%)$. After inadequate operations elsewhere, there was a higher incidence of late local recurrence $(\mathbf{2 8 . 3 \%})$, in comparison with those with primary tumours treated by us $(\mathbf{9 . 0 \%})$, or patients referred to us immediately after inadequate surgery elsewhere $(10.2 \%)$. Because of small numbers these differences in the survival rates were not statistically significantly different.

Univariate survival analysis showed that local recurrence after definitive surgery $(p=0.006)$ together with the histological grade $(p=0.0002)$, the size of the tumour $(p=0.002)$, its depth in relation to deep fascia $(p=0.003)$, and the surgical margin $(p=0.0001)$ were the significant prognostic factors. Local recurrence at the initial presentation did not affect survival. Multivariate analysis showed that local recurrence after definitive surgery also lost its apparent prognostic significance.

J Bone Joint Surg [Br] 1997;79-B:553-7.

Received 6 December 1996; Accepted after revision 14 February 1997

T. Ueda, MD, Musculoskeletal Tumour Surgeon

H. Yoshikawa, MD, Chief of Musculoskeletal Tumour Surgery

S. Mori, MD, Musculoskeletal Tumour Surgeon

Department of Orthopaedic Surgery, Osaka Medical Centre for Cancer and Cardiovascular Diseases, 1-3-3 Nakamichi, Higashinari-ku, Osaka 537, Japan.

N. Araki, MD, Musculoskeletal Tumour Surgeon

A. Myoui, MD, Musculoskeletal Tumour Surgeon

S. Kuratsu, MD, Musculoskeletal Tumour Surgeon

A. Uchida, MD, Chief of Musculoskeletal Tumour Surgery

Department of Orthopaedic Surgery, Osaka University Medical School,

2-2 Yamadaoka, Suita 565, Japan.

Correspondence should be sent to Dr T. Ueda.

(c)1997 British Editorial Society of Bone and Joint Surgery 0301-620X/97/47487\$2.00
Soft-tissue sarcomas (STS) are relatively rare, comprising about $0.7 \%$ of all cancers, but $60 \%$ to $70 \%$ of all tumours arising in the limbs. Over the past two decades, the management of these lesions has changed dramatically. Wide local excision combined with adjuvant radiotherapy, chemotherapy, or both has become standard instead of ablative surgery such as amputation. ${ }^{1-4}$ Unfortunately, inadequate initial surgery of primary tumours is still frequent, before consultation with referral centres. This results in a high incidence of local recurrence, reported as between $50 \%$ and $80 \% .^{5-7}$ Even after a radical operation, there is local recurrence in about $5 \%$ to $10 \%$ of patients, although the impact of this on survival remains uncertain. ${ }^{8,9}$ Some previous reports ${ }^{5,10-13}$ indicate that this is a grave prognostic sign, but others disagree. ${ }^{14-19}$ Evans ${ }^{9}$ has recently suggested the importance of distinguishing two manifestations of locally recurrent disease stating that "Local recurrence following radical surgery is a grave sign, but local recurrence following limited surgery, which is labelled 'local persistence' is often an innocent event".

With this in mind we have analysed the impact on the prognosis of local recurrence using a prospectively compiled database of 173 consecutive patients with localised STS of the limbs or trunk. We classified local recurrences according to whether they were present before referral to us or after definitive surgery at our hospitals.

\section{PATIENTS AND METHODS}

Between 1976 and 1992, 214 patients were referred to the Departments of Orthopaedic Surgery in the Osaka University Medical School and the Osaka Medical Center for Cancer and Cardiovascular Diseases, with STS of the limbs or trunk. Of these, 41 were excluded from the study: 26 had distant metastasis when first seen, four had definitive surgery performed elsewhere, five had an extra-abdominal desmoid tumour, five an infantile fibrosarcoma and one was lost to follow-up. The remaining 173 patients were assessed and their clinicopathological characteristics are summarised in Table I.

There were 101 males and 72 females with a median age of 44 years ( 3 to 85 ). They were divided into three groups as follows: group A $(n=78)$, initially treated at our hospi- 
Table I. Details of 173 patients with soft-tissue sarcoma, by number and percentage

\begin{tabular}{|c|c|c|}
\hline \multicolumn{3}{|l|}{ Characteristics } \\
\hline \multicolumn{3}{|l|}{ Gender } \\
\hline Male & 101 & 58 \\
\hline Female & 72 & 42 \\
\hline Median age in years (range) & \multicolumn{2}{|c|}{$44(3$ to 85$)$} \\
\hline \multicolumn{3}{|l|}{ Status at presentation } \\
\hline Primary & 78 & 45 \\
\hline Immediately after resection elsewhere & 49 & 28 \\
\hline Locally recurrent & 46 & 27 \\
\hline \multicolumn{3}{|l|}{ Primary site } \\
\hline Upper limb & 25 & 14 \\
\hline Lower limb & 97 & 56 \\
\hline Trunk* & 51 & 30 \\
\hline \multicolumn{3}{|l|}{ Tumour size (cm) } \\
\hline$\leq 5$ & 64 & 37 \\
\hline$>5$ & 103 & 60 \\
\hline Unknown & 6 & 3 \\
\hline \multicolumn{3}{|l|}{ Tumour depth } \\
\hline Superficial & 38 & 22 \\
\hline Deep & 114 & 66 \\
\hline Unknown & 21 & 12 \\
\hline \multicolumn{3}{|l|}{ Histological grade } \\
\hline Low $(\mathrm{G} 1)$ & 48 & 28 \\
\hline Intermediate (G2) & 49 & 28 \\
\hline High (G3) & 76 & 44 \\
\hline \multicolumn{3}{|l|}{ Histological type } \\
\hline Malignant fibrous histiocytoma & 51 & 30 \\
\hline Liposarcoma & 31 & 18 \\
\hline Synovial sarcoma & 25 & 15 \\
\hline Malignant peripheral nerve-sheath tumour & 15 & 9 \\
\hline Dermatofibrosarcoma protuberans & 9 & 5 \\
\hline Leiomyosarcoma & 6 & 3 \\
\hline Rhabdomyosarcoma & 6 & 3 \\
\hline Fibrosarcoma & 4 & 2 \\
\hline Others & 26 & 15 \\
\hline
\end{tabular}

tals; group B ( $n=49)$, referred to our hospitals immediately after inadequate surgery elsewhere; and group C $(n=46)$, treated after local recurrence following previous surgery elsewhere. The lower limbs were the site of the primary tumour in 97 patients, the trunk including the limb girdles in 51, and the upper limbs in 25 . The size of the tumour was defined as its maximum diameter. Its depth was estimated relative to the neighbouring fascia and defined as superficial or deep.

The histological diagnosis according to the criteria of Enzinger and Weiss, ${ }^{20}$ was malignant fibrous histiocytoma (MFH) in 51 patients, liposarcoma in 31, synovial sarcoma in 25, malignant peripheral nerve-sheath tumour (MPNST) in 15, dermatofibrosarcoma protuberans in 9, leiomyosarcoma in 6 , rhabdomyosarcoma in 6 , fibrosarcoma in 4 , and other types of sarcoma in 26. The distribution of the histological grading, based on our criteria previously described, ${ }^{6,21}$ was low grade (G1) in 48 tumours, intermediate grade (G2) in 49 , and high grade (G3) in 76 . The clinical stages were determined according to the American Joint Committee (AJC) staging system ${ }^{22}$ as stage Ia in 15 cases, Ib in 29, IIa in 20, IIb in 27, IIIa in 26, IIIb in 43, and IVa with regional lymph node metastasis in 7.
Table II. Types of treatment performed in 173 patients, by number and percentage

\begin{tabular}{lrr}
\hline Treatment & & \\
\hline Surgical procedure & & \\
$\quad$ Wide local excision & 140 & 81 \\
Marginal excision & 4 & 2 \\
Intralesional excision & 14 & 8 \\
$\quad$ Amputation/or disarticulation & & \\
Adjuvant radiotherapy & 30 & 17 \\
$\quad$ Postoperatively (+) & 7 & 4 \\
$\quad$ Preoperatively (+) & 2 & 1 \\
Pre- and postoperatively (+) & 134 & 78 \\
$\quad$ None & & \\
Adjuvant chemotherapy & 89 & 51 \\
$\quad$ Pre- and postoperatively (+) & 31 & 18 \\
Postoperatively (+) & 20 & 12 \\
Preoperatively (+) & 33 & 19 \\
$\quad$ None & & \\
\hline
\end{tabular}

Table II gives details of the surgical and adjuvant treatment performed. The definitive surgery at our hospitals was carried out with the intention of achieving a cure. It included wide local excision in 140 patients, marginal excision in 15 , intralesional excision in 4 , and wide amputation/or disarticulation in 14. Most patients (92\%) had limb-sparing surgery. The surgical margin was evaluated in all except 13 patients by examination of the resected specimens and was defined as adequate for those with more than a wide margin in all planes $(n=126)$ and inadequate for those with a marginal or intralesional margin in at least one plane $(n=34)$. Thirty-nine patients received adjuvant radiotherapy. This was after operation in 30 , before in seven, and both before and after in two patients for tumours which were unlikely to have local control by surgery alone. The total doses of radiotherapy used ranged from 28 to $70 \mathrm{~Gy}$ (mean 46.7). Adjuvant chemotherapy was used in 140 patients: both before and after operation in 89 , before operation only in 20 and after only in 31 . The chemotherapeutic regimens varied, but mostly included doxorubicin as well as ifosfamide, vincristine, and cisplatinum.

Statistical analysis. The follow-up period for all patients was calculated from the date of the initial definitive operation and ranged from 5 to 216 months (median: 48 months for all patients, 59 months for survivors). Actuarial survival curves were constructed using the method of KaplanMeier, ${ }^{23}$ and the log-rank test for survival analysis ${ }^{24}$ was used to estimate the prognostic significance of the clinicopathological variables. The presence of local recurrence before referral or after definitive surgery at our hospitals was analysed separately.

We performed multivariate analysis using Cox's proportional hazards model ${ }^{25}$ to identify the independent prognostic factors. For variables analysed by multivariate analysis, relative risks with $95 \%$ confidence intervals (CI) were calculated. These analyses were performed using JMP statistical computer software version 3.1 (SAS Institute, Cary, North Carolina). 


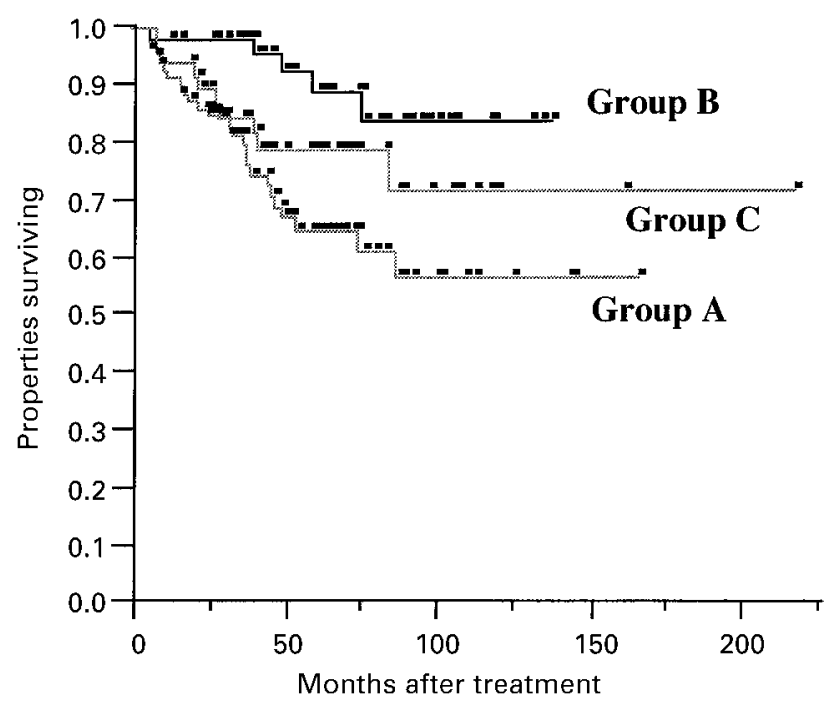

Fig. 1

Actuarial overall survival curves for each group according to the status at initial presentation. Group A, those who were initially treated $(n=78)$; group $\mathrm{B}$, those referred immediately after inadequate surgery elsewhere $(n=49)$; group $C$, those who were treated after local recurrence after previous surgery elsewhere $(n=46)$. The dots represent censored observations.

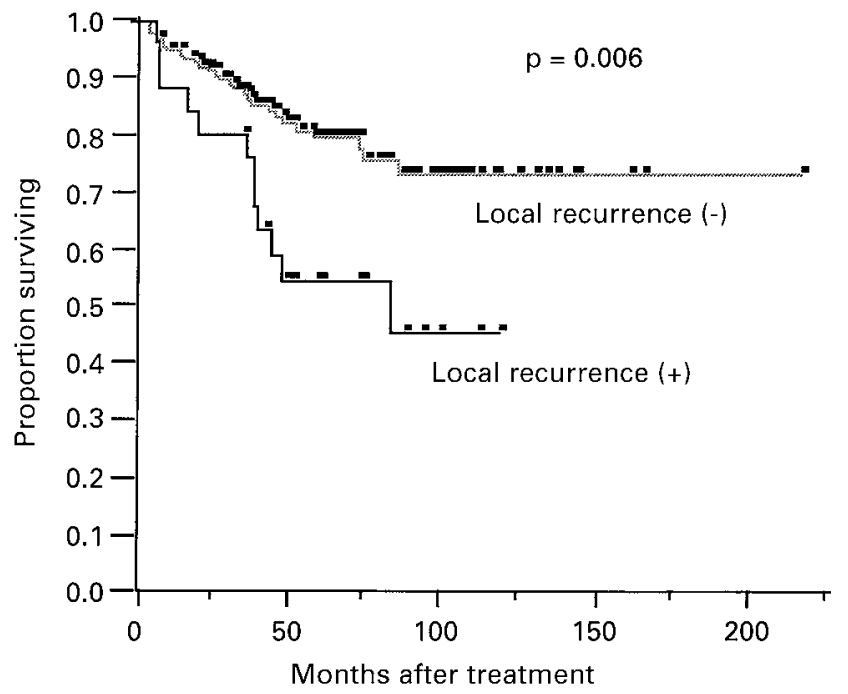

Fig. 2

Actuarial overall survival curves for patients with or without local recurrence after definitive surgery at our hospitals. The dots represent censored observations.

\section{RESULTS}

The actuarial overall five- and ten-year survival rates were $75.2 \%$ (95\% CI $67.9 \%$ to $82.4 \%$ ) and $68.0 \%$ (95\% CI $58.6 \%$ to $77.4 \%$ ), respectively. Local recurrence after definitive surgery occurred in 25 of the 173 patients $(14.5 \%)$. The median time to development of local recurrence after definitive surgery was 20 months (3 to 97). Assessment of recurrence according to the groups previously defined showed the local rate in group $\mathrm{C}$ to be $28.3 \%$, relatively higher than in group A $(9.0 \%)$ and group B (10.2\%). The
Table III. Univariate analysis for prognostic factors

\begin{tabular}{|c|c|c|}
\hline Variables & $\begin{array}{l}\text { Five-year } \\
\text { survival rate }(\%)\end{array}$ & p value \\
\hline \multicolumn{3}{|l|}{ Gender } \\
\hline Male & 74.8 & \\
\hline Female & 76.2 & 0.35 \\
\hline \multicolumn{3}{|l|}{ Age $(y r)$} \\
\hline$<45$ & 76.8 & \\
\hline$\geq 45$ & 73.3 & 0.33 \\
\hline \multicolumn{3}{|l|}{ Primary site } \\
\hline Upper limb & 68.7 & \\
\hline Lower limb & 79.5 & \\
\hline Trunk* & 69.3 & 0.76 \\
\hline \multicolumn{3}{|l|}{ Tumour size $(\mathrm{cm})$} \\
\hline$\leq 5$ & 90.3 & \\
\hline$>5$ & 66.7 & 0.002 \\
\hline \multicolumn{3}{|l|}{ Tumour depth } \\
\hline Superficial & 96.6 & \\
\hline Deep & 69.4 & 0.003 \\
\hline \multicolumn{3}{|l|}{ Histological grade } \\
\hline Low (G1) & 95.5 & \\
\hline Intermediate (G2) & 78.9 & \\
\hline High (G3) & 60.1 & 0.0002 \\
\hline \multicolumn{3}{|l|}{ Histological type } \\
\hline Malignant fibrous histiocytoma & 78.9 & \\
\hline Liposarcoma & 86.7 & \\
\hline Synovial sarcoma & 66.4 & \\
\hline $\begin{array}{l}\text { Malignant peripheral nerve-sheath } \\
\text { tumour }\end{array}$ & 59.1 & \\
\hline Dermatofibrosarcoma protuberans & 100.0 & \\
\hline Leiomyosarcoma & 83.3 & \\
\hline Rhabdomyosarcoma & 50.0 & \\
\hline Fibrosarcoma & 75.0 & \\
\hline Others & 67.3 & 0.33 \\
\hline \multicolumn{3}{|l|}{ Surgical margin } \\
\hline Adequate & 81.7 & \\
\hline Inadequate & 44.6 & 0.0001 \\
\hline \multicolumn{3}{|l|}{$\begin{array}{l}\text { Local recurrence } \\
\text { at initial presentation }\end{array}$} \\
\hline Absent & 74.1 & \\
\hline Present & 78.7 & 0.84 \\
\hline \multicolumn{3}{|l|}{ After definitive surgery } \\
\hline Absent & 79.5 & \\
\hline Present & 54.1 & 0.006 \\
\hline
\end{tabular}

actuarial overall survival rate of group $\mathrm{C}$, however, was not significantly worse than that of groups A and B (Fig. 1). To estimate the prognostic significance of local recurrence before referral to our hospitals, groups A and B were summed, and their overall survival rate compared with that of group C. Again there was no significant difference in survival between group $\mathrm{A}+\mathrm{B}$ and group $\mathrm{C}$.

Univariate analysis for prognostic factors. Table III gives the results of univariate survival analysis according to various clinicopathological factors. The histological grade (G1 $v \mathrm{G} 2 v \mathrm{G} 3, \mathrm{p}=0.0002)$, the size of the tumour $(\leq 5 \mathrm{~cm}$ $v>5 \mathrm{~cm}, \mathrm{p}=0.002$ ), the depth of the lesion (superficial $v$ deep, $\mathrm{p}=0.003$ ), and the surgical margin (adequate $v$ inadequate, $\mathrm{p}=0.0001$ ) were the significant prognostic factors. Local recurrence after definitive surgery at our hospitals (absent $v$ present, $\mathrm{p}=0.006$ ) was also significantly associated with patient survival (Fig. 2), whereas the presence 
Table IV. Multivariate analysis for prognostic factors

\begin{tabular}{|c|c|c|}
\hline Variables & Risk ratio & $95 \%$ CI \\
\hline $\begin{array}{l}\text { Tumour size }(\mathrm{cm}) \\
\quad \leq 5 \\
>5\end{array}$ & 3.12 & 1.26 to 9.62 \\
\hline $\begin{array}{l}\text { Tumour depth } \\
\text { Superficial } \\
\text { Deep }\end{array}$ & 6.35 & 1.29 to 115 \\
\hline $\begin{array}{l}\text { Histological grade } \\
\text { Low (G1) } \\
\text { Intermediate (G2) } \\
\text { High (G3) }\end{array}$ & $\begin{array}{l}8.72 \\
2.47\end{array}$ & $\begin{array}{l}1.56 \text { to } 163 \\
1.17 \text { to } 5.69\end{array}$ \\
\hline $\begin{array}{l}\text { Surgical margin } \\
\quad \text { Adequate } \\
\text { Inadequate }\end{array}$ & 3.62 & 1.49 to 8.50 \\
\hline $\begin{array}{l}\text { Local recurrence } \\
\text { At initial presentati } \\
\text { Absent } \\
\text { Present }\end{array}$ & 1.09 & 0.45 to 2.44 \\
\hline $\begin{array}{l}\text { After definitive surg } \\
\text { Absent } \\
\text { Present }\end{array}$ & 0.95 & 0.37 to 2.36 \\
\hline
\end{tabular}

of local recurrence at the initial presentation did not affect survival.

Multivariate analysis for prognostic factors. Using the data for the 143 patients for whom we had full clinical information, the five significant prognostic factors selected in the univariate analysis together with local recurrence at initial presentation were subjected to multivariate analysis. The histological grade, the size of the tumour, its depth, and surgical margin proved to be the significant prognostic factors (Table IV), as has previously been shown in many other studies. $^{5,6,11,19,26-31}$ Neither local recurrence at initial presentation nor after definitive surgery at our hospitals had prognostic significance in the multivariate analysis.

\section{DISCUSSION}

It is agreed that local control of primary STS is essential. Wide local excision with or without adjuvant radiotherapy is now standard for lesions in the limbs in order to avoid amputation. Inadequate surgery is still frequently performed, however, before proper consultation with specialist centres, resulting in a high incidence of local recurrence, which has long been considered to be an ominous prognostic sign. ${ }^{5,10-13}$ Several recent reports, however, have suggested that local recurrence does not adversely affect survival, ${ }^{14-19}$ but Pisters et al ${ }^{30}$ have recently indicated that patients with locally recurrent disease when first seen are at increased risk of subsequent local recurrence and of death from the disease.

As Evans ${ }^{9}$ has pointed out, there are two patterns of local recurrence: first, that following a limited operation with an inadequate surgical margin, so-called 'local persistence', and secondly local recurrence after radical surgery with an adequate surgical margin. We have confirmed that the former type does not affect patient survival. Initial pre- sentation to us with local recurrence after inadequate surgery elsewhere, however, was associated with a subsequent higher rate of local recurrence than patients presenting primarily to us $(28.3 \% v 9.0 \%)$. Local recurrence after a definitive operation aimed at cure at our hospitals, however, was a significantly unfavourable prognostic factor in univariate analysis, but not in multivariate analysis. This is because other independent prognostic factors such as the histological grade, the size and depth of the tumour and the surgical margin influence the prognosis to a much greater degree. Gaynor et al $^{28}$ also suggested that local recurrence may be an unfavourable prognostic factor, but only in patients whose tumours had become more aggressive at the time of the local recurrence. Thus, local recurrence appears to be a marker for, rather than a cause of, the poor prognosis, and, indeed, a significant risk factor in the survival of patients with small and/or low-grade tumours. $^{32,33}$

We have previously reported that increases in cellularity and mitotic counts occurring during repeated recurrences of STS indicate an unfavourable prognosis. ${ }^{34}$ Wide local excision with an adequate surgical margin is thus considered critical for patients with small and/or low-grade tumours in order to improve their prognosis. In patients with large and/ or high-grade tumours which are both locally and distantly aggressive, ${ }^{16,17}$ however, local control by wide local excision with or without radiotherapy does not necessarily contribute to an improvement in survival when the patients already require maximum treatment combined with adjuvant chemotherapy to prevent distant metastases.

This work was supported in part by a grant from the Japanese Ministry of Health and Welfare.

No benefits in any form have been received or will be received from a commercial party related directly or indirectly to the subject of this article.

\section{REFERENCES}

1. Rosenberg SA, Tepper J, Glatstein E, et al. The treatment of softtissue sarcomas of the extremities: prospective randomised evaluations of (1) limb-sparing surgery plus radiation therapy compared with amputation and (2) the role of adjuvant chemotherapy. Ann Surg 1982; 196:305-15.

2. Karakousis CP, Emrich LJ, Rao U, Krishnamsetty RM. Feasibility of limb salvage and survival in soft tissue sarcomas. Cancer 1986; 57:484-91.

3. Brennan MF, Casper ES, Harrison LB, et al. The role of multimodality therapy in soft-tissue sarcoma. Ann Surg 1991;214:328-38.

4. Lise M, Rossi CR, Alessio S, Foletto M. Multimodality treatment of extra-visceral soft tissue sarcomas M0: state of the art and trends. Eur J Surg Oncol 1995;21:125-35.

5. Markhede G, Angervall L, Stener B. A multivariate analysis of the prognosis after surgical treatment of malignant soft-tissue tumors. Cancer 1982;49:1721-33.

6. Ueda T, Aozasa K, Tsujimoto $M$, et al. Multivariate analysis for clinical prognostic factors in 163 patients with soft tissue sarcoma. Cancer 1988;62:1444-50.

7. Gustafson P, Dreinhofer KE, Rydholm A. Soft tissue sarcoma should be treated at a tumor center: a comparison of quality of surgery in 375 patients. Acta Orthop Scand 1994;65:47-50.

8. Barr LC, Stotter AT, A'Hern RP. Influence of local recurrence on survival: a controversy reviewed from the perspective of soft tissue sarcoma. Br J Surg 1991;78:648-50.

9. Evans RA. Soft tissue sarcoma: the enigma of local recurrence. J Surg Oncol 1993;53:88-91. 
10. Cantin J, McNeer GP, Chu FC, Booher RJ. The problem of local recurrence after treatment of soft tissue sarcoma. Ann Surg 1968; 168:47-53.

11. Rööser B, Attewell R, Berg NO, Rydholm A. Survival in soft tissue sarcoma: prognostic variables identified by multivariate analysis. Acta Orthop Scand 1987;58:516-22.

12. Emrich LJ, Ruka W, Driscoll DL, Karakousis CP. The effect of local recurrence on survival time in adult high-grade soft tissue sarcomas. J Clin Epidemiol 1989;42:105-10.

13. Stotter AT, A'Hern RP, Fisher C, et al. The influence of local recurrence of extremity soft tissue sarcoma on metastasis and survival. Cancer 1990;65:1119-29.

14. Potter DA, Glenn J, Kinsella T, et al. Patterns of recurrence in patients with high-grade soft-tissue sarcomas. J Clin Oncol 1985;3: 353-66.

15. Brennan MF. Management of extremity soft-tissue sarcoma. Am J Surg 1989;158:71-8

16. Rööser B, Gustafson P, Rydholm A. Is there no influence of local control on the rate of metastases in high-grade soft tissue sarcoma? Cancer 1990;65:1727-9.

17. Gustafson P, Rööser B, Rydholm A. Is local recurrence of minor importance for metastases in soft tissue sarcoma? Cancer 1991;67: 2083-6.

18. Singer S, Antman K, Corson JM, Eberlein TJ. Long-term salvageability for patients with locally recurrent soft-tissue sarcomas. Arch Surg 1992; 127:548-54.

19. Singer S, Corson JM, Gonin R, Labow B, Eberlein TJ. Prognostic factors predictive of survival and local recurrence for extremity soft tissue sarcoma. Ann Surg 1994;219:165-73.

20. Enzinger FM, Weiss SW. Soft tissue tumours. 3rd ed. St. Louis: Mosby, 1995:4-9.

21. Tsujimoto M, Aozasa K, Ueda T, et al. Multivariate analysis for histologic prognostic factors in soft tissue sarcomas. Cancer 1988; 62:994-8.

22. American Joint Committee on Cancer. Manual for staging of cancer. 4th ed. Philadelphia, JB Lippincott, 1992:131-6.
23. Kaplan EL, Meier P. Nonparametric estimation from incomplete observations. J Am Stat Assoc 1958;53:457-81.

24. Peto R, Pike MC, Armitage, et al. Design and analysis of randomized clinical trials requiring prolonged observation of each patient. II. Analysis and examples. Br J Cancer 1977;35:1-39.

25. Cox DR. Regression models and life tables. J Roy Stat Soc 1972;34: 187-220.

26. Collin CF, Freidrich C, Godbold J, Hadju S, Brennan MF. Prognostic factors for local recurrence and survival in patients with localised extremity soft-tissue sarcoma. Semin Surg Oncol 1988;4: 30-7.

27. Bell RS, O'Sullivan B, Liu FF, et al. The surgical margin in softtissue sarcoma. J Bone Joint Surg [Am] 1989;71-A:370-5.

28. Gaynor JJ, Tan CC, Casper ES, et al. Refinement of clinicopathologic staging for localised soft tissue sarcoma of the extremity: a study of 423 adults. J Clin Oncol 1992;10:1317-29.

29. Herbert SH, Corn BW, Solin LJ, et al. Limb-preserving treatment for soft tissue sarcomas of the extremities: the significance of surgical margins. Cancer 1993;72:1230-8.

30. Pisters PW, Leung DH, Woodruff J, Shi W, Brennan MF. Analysis of prognostic factors in 1041 patients with localised soft tissue sarcomas of the extremities. J Clin Oncol 1996;14:1679-89.

31. Coindre JM, Terrier P, Bui NB, et al. Prognostic factors in adult patients with locally controlled soft tissue sarcoma: a study of 546 patients from the French Federation of Cancer Centers Sarcoma Group. J Clin Oncol 1996;14:869-77.

32. Trovik CS, Bauer HC. Local recurrence of soft tissue sarcoma, a risk factor for late metastases: 379 patients followed for 0.5 to 20 years. Acta Orthop Scand 1994;65:553-8.

33. Tomita Y, Kuratsu S, Naka N, Uchida A, Ono K, Ohsawa M, Aozasa K. A staging system for soft-tissue sarcoma and its evaluation in relation to treatment. Int J Cancer 1994;58:168-73.

34. Tsujimoto M, Aozasa K, Ueda T, Aoki Y, Orihara M, Mizushima T, et al. Histological changes in recurrent soft-tissue sarcomas: analysis of 56 patients. Jpn J Clin Oncol 1988;18:135-42. 